\title{
ASPEK YURIDIS PENYELENGGARAAN FINANCIAL TECHNOLOGY BERBASIS PEER TO PEER LENDING
}

\author{
Anita ${ }^{(1)}$ \\ Rusfandi ${ }^{(2)}$ \\ ${ }^{(1,2)}$ Dosen Fakultas Hukum Universitas Wiraraja \\ anitafh@wiraraja.ac.id ${ }^{(1)}$ \\ rusfandi@wiraraja.ac.id ${ }^{(2)}$
}

\begin{abstract}
ABSTRAK
Para pihak dalam penyelenggaraan Financial Technology berbasis Peer to peer Lending di Indonesia terdiri dari pemberi pinjaman, penyelenggara dan penerima pinjaman. Sejak adanya penyelenggaraan peminjaman uang berbasis teknologi ini yang menjadi isu utama adalah bentuk perlindungan hukum khusunya bagi pemberi pinjaman, pemberi pinjaman sebagai Investor harus dilindungi agar dananya tidak hilang atau disalahgunakan oleh pihak penyelenggara dan agar dananya tidak hilang akibat gagal bayar oleh pihak penerima pinjaman (debitor). Metode penelitian hukum yang digunakan adalah yuridis normatif dengan pendekatan perundang-undangan (Statute Approach). Hasil Penelitian ini yaitu mengetahui Aspek yuridis berupa bentuk perlindungan hukum bagi pemberi pinjaman dapat dilakukan secara preventif maupun secara represif. Perlindungan hukum secara preventif digunakan untuk mencegah agar tidak terjadi sengketa bisnis pinjam meminjam uang berbasis teknologi. Perlindungan secara preventif tugasnya terletak pada penyelenggara Fintech dimana, penyelenggara harus memenuhi persyaratan mengajukan izin menjadi penyelenggara kepada OJK sebagaimana disebutkan dalam Pasal 3 Peraturan OJK. Perlindungan secara represif yaitu jika telah terjadi sengketa karena kelalaian dan kealasahan dari pihak penyelenggara, maka penyelenggara wajib melakukan ganti rugi sebagaimana disebutkan dalam pasal 37 PJOK No. 77/PJOK.01/2016.
\end{abstract}

Kata Kunci : : Aspek Yuridis, Financial Technology dan Peer to Peer Lending 


\section{A. PENDAHULUAN}

Perkembangan lembaga keuangan di Indonesia dewasa ini mengalami peningkatan yang sangat pesat sebagai dampak dari perkembangan perekonomian dan arus globalisasi. Lembaga keuangan memiliki peranan yang sangat penting bagi pertumbuhan perekonomian suatu Negara. Lembaga keuangan dapat menjadi fasilitator yang mempertemukan pemberi pinjaman yaitu pihak yang kelebihan dana (surplus funds) dan pihak yang kekurangan dana (lack of funds). Seiring perkembangan zaman lembaga keuangan di Indonesia semakin banyak dan bervariasi, baik dalam bentuk bidang perbankan atau non perbankan. Bidang perbankan seperti bank konvensional dan bank syariah yang telah banyak berkembang di Indonesia sedangkan bidang non perbankan seperti lembaga asuransi, reksa dana, pegadaian dan lembaga keuangan lainnya.

Perkembangan perekonomian di Indonesia pada dasarnya bertumpu pada perbankan. keberadaan bank bertujuan untuk menunjang pelaksanaan pembangunan nasional dalam rangka meningkatkan pemerataan dan pertumbuhan ekonomi. sebagaimana bunyi pasal 1 ayat (2) Undang-Undang No. 10 Tahun 1998 Perubahan atas UndangUndang No. 7 tahun 1992 tentang Perbankan menyatakan bahwa bank adalah badan usaha yang menghimpun dana dari masyarakat dalam bentuk simpanan danmenyalurkannya kepada masyarakat dalam bentuk kredit dan atau bentukbentuk lainnya dalam rangka meningkatkan taraf hidup rakyat banyak.

Menurut Djoni S. Gazali dan Rachmadi Usman bank adalah sebagai salah satu lembaga keuangan yang fungsi utamanya sebagai penghimpun dana dan menyalurkan dana masyarakat. ${ }^{1}$ Bank berfungsi sebagai sarana pemberdayaan masyarakat, pemusatan ekonomi nasional utamanya bagi para pengusaha, usaha mikro kecil dan menengah serta koperasi untuk mendapatkan dana serta bank berfungsi sebagai agen pembangunan yang bertujuan mendukung pelaksanaan pembangunan nasional dalam rangka pemerataan pembangunan.

Namun kenyataannya, tidak semua masyarakat Indonesia tersentuh dengan pelayanan jasa perbankan. Hal tersebut dikarenakan letak geografis negara Indonesia yang terdiri dari pulaupulau yang menyebabkan ada beberapa daerah yang sulit dan agak tertinggal untuk mendapatkan jasa pelayanan perbankan (unbanked people). Layanan perbankan hanya berpusat di kota saja dan kurang menyentuh ke daerah, yang

\footnotetext{
${ }^{1}$ Djoni S. Gazali, Rachmadi Usman, Hukum Perbankan, Sinar Grafika, Jakarta, 2016, h. 1
} 
menyebabkan terjadi kesenjangan kesejahteraan akibat tidak meratanya pembangunan ekonomi nasional.

Kurang tersentuhnya masyarakat pelosok daerah terhadap pelayanan jasa perbankan menjadi realitas di negara berkembang seperti Indonesia bahwa masih banyak masyarakat yang tidak mengetahui dan memiliki akses terhadap layanan jasa perbankan. Realitas tersebut disampaikan oleh Menteri PPN/Kepala Bappenas Bambang PS Brodjonegoro mengatakan, survey dari World Bank terhadap Indonesia membuktikan bahwa pada 2014, baru $37 \%$ penduduk dewasa memiliki rekening bank. Data ini diperparah dengan presentase hanya $27 \%$ masyarakat yang memiliki simpanan formal dan $13 \%$ memiliki pinjaman formal. $^{2}$

Sedangkan Survey yang dilakukan oleh Otoritas Jasa Keungan menyatakan bahwa Pada 2016 Otoritas Jasa Keuangan (OJK) mencatat bahwa menurut survey, hanya $28,9 \%$ penduduk dewasa memahami produk-produk perbankan Indonesia. ${ }^{3}$ Angka ini jauh lebih rendah dari negaranegara lain di Asia. Ini akibat dari rendahnya akses keuangan diikuti rendahnya literasi keuangan. Tidak hanya itu, tingkat pemahaman ini semakin rendah

\footnotetext{
${ }^{2}$ Disfiyant Glienmourinsie, "Tingkat Pemahaman Masyarakat Soal Produk Keuangan Masih Rendah", SindoNews.com, 23 September 2018. ${ }^{3}$ Ibid.
}

untuk produk jasa keuangan lainnya.

Seiring pesatnya arus globalisasi tentunya tidak lepas dari perkembangan teknologi informasi. Khususnya internet dan gadget yang sangat membantu memudahkan kehidupan manusia di era saat ini. Perkembangan teknologi tersebutlah yang mendorong lahirnya bisnis dan perdagangan secara elektronik yang dikenal dengan bisnis online dan perdagangan elektronik (e-commerce).

Generasi muda zaman sekarang lebih senang berselancar dan beraktivitas menggunakan media Internet baik hanya untuk bersosialisasi (melalui media sosial) maupun dalam hal bertransaksi seperti transaksi jual beli maupun pembayaran secara online. Hal ini yang mendorong munculnya aplikasi sistem pembayaran secara online yang dinilai lebih mudah dan praktis dibandingkan dengan sistem pembayaran menggunakan uang, cek, kartu kredit dll. Dari kemudahan yang dapat diakses melalui internet menyebabkan lahirnya sistem Peminjaman Uang secara online yang dikenal dengan Financial Technology berbasis Peer to Peer Lending (Fintech berbasis $P 2 P$ lending).

Fintech berasal dari istilah Financial Technology atau Teknologi Finansial. Menurut The National Digital Research Centre (NDRC), Fintech merupakan suatu inovasi pada sektor 
finansial. Tentunya, inovasi finansial ini mendapat sentuhan teknologi modern. Keberadaan Fintech dapat mendatangkan proses transaksi keuangan yang lebih praktis dan aman. ${ }^{4}$

Fintech merupakan penyampaian produk dan layanan keuangan melalui kolaborasi Platform teknologi dan model bisnis inovatif. Asal usul Fintech berasal dari Silicon Valley, kemudian meluas ke New York, London, Singapura, Hongkong dan beberapa kota global lainnya. The Fintech 100 daftar yang menyebutkan 50 perusahaan Fintech terkemuka dan 50 Start $U p$ yang paling menjanjikan telah dibentuk untuk merayakan kesuksesan ini. Menurut Fintech 100, Contoh kisah sukses Fintech antara lain : ZhongAn (perusahaan patungan antara Alibaba, Group Holding, Tancent Holdings dan Ping An Insurance yang memanfaatkan data besar untuk menyediakan asuransi properti online), Wealthfront (Perusahaan yang memberikan layanan manajemen investasi yang terjangkau namun canggih), dan Kreditech (Perusahaan yang menyediakan layanan keuangan dengan fokus akses kredit). ${ }^{5}$

Fintech merupakan implementasi dan pemanfaatan teknologi untuk

4 Fauziah Hadi, Penerapan Financial Technology (Fintech) sebagai Inovasi Pengembangan Keuangan Digital di Indonesia.

5 Ross P. Buckley, "FinTech in Developing Countries : Charting New Costumers Journeys" Jurnal : The Capco Institute Journal of Financial Transformation. 2016. h.5. peningkatan layanan jasa perbankan dan keuangan yang umumnya dilakukan oleh perusahaan rintisan (startup) dengan memanfaatkan teknologi software, internet, komunikasi, dan komputasi terkini. ${ }^{6}$ Proses Fintech meliputi pembuatan software, Pengolahan sistem hingga output yang biasa dilakukan oleh lembaga keuangan untuk mempermudah konsumen dalam melakukan proses transaksi. Kemunculan Fintech tentunya tidak lepas dari inovasi teknologi internet dan peralatan canggih berupa Gadget (PC, Laptop, Notebook, Smartphone, tablet) yang berperan besar mendorong pesatnya bisnis Fintech di dunia.

Bentuk dasar Fintech meliputi Pembayaran (digital wallets, P2P payments) Investasi (equity crowdfunding, P2P lending) Pembiayaan (crowdfunding, micro-loans, credit facilities) Asuransi (risk management) Lintas-proses (big data analysis, predictive modeling) Infrastruktur (security). ${ }^{7}$ Melalui Fintech masyarakat dapat dengan mudah mengakses berbagai macam aplikasi seperti sistem pembayaran menggunakan aplikasi dompet elektronik (e-wallet) kemudian masyarakat juga dapat mengakses pinjaman uang melalui perusahaan-

\footnotetext{
6 Nofie Iman, Financial Technology dan Lembaga Keuangan, Gathering Mitra Linkage Bank Syariah Mandiri, Yogyakarta, 2016, hlm. 6.

${ }^{7}$ Ibid. h. 7.
} 
perusahaan dalam bidang layanan pinjam meminjam uang berbasis teknologi informasi (Peer to Peer atau P2P Lending).

Layanan Pinjam meminjam uang berbasis teknologi (Peer to Peer atau P2P Lending) ini merupakan salah satu solusi menjawab minimnya masyarakat Indonesia yang karena faktor geografis tidak dapat tersentuh layanan jasa perbankan (Unbanked People) maupun lembaga keuangan lainnya akan tetapi dapat menggunakan dan mengakses teknologi dengan baik. Fintech berbasis $P 2 P$ Lending bertindak seperti lembaga perbankan namun beroperasi melalui internet dan teknologi yang canggih. Pinjam meminjam uang atau utang piutang telah lazim dilakukan di tengah masyarakat berdasarkan perjanjian yaitu pihak yang kelebihan dana meninjamkan kepada pihak yang kekurangan dana berdasarkan atas "asas kebebasan berkontrak" yang diatur dalam Kitab Undang-Undang Hukum Perdata (KUH Perdata). Namun bedanya dengan Fintech berbasis $P 2 P$ lending yaitu biasanya para pihak khususnya peminjam uang adalah mereka generasi muda milenial yang tergolong sebagai pelaku usaha mikro.

Para pihak dalam Fintech berbasis P2P lending terdiri dari Pemberi Pinjaman, Penyelenggara dan Penerima Pinjaman. Pemberi pinjaman adalah orang, badan hukum, dan/atau badan usaha yang mempunyai piutang karena perjanjian
Layanan Pinjam Meminjam Uang Berbasis Teknologi Informasi. ${ }^{8}$ Pemberi pinjaman yaitu masyarakat baik perseorangan, badan hukum atau badan usaha yang meng investasikan kelebihan dananya kepada penyelenggara. Pihak yang kedua adalah Penyelenggara Layanan Pinjam Meminjam Uang Berbasis Teknologi Informasi yang selanjutnya disebut Penyelenggara adalah badan hukum Indonesia yang menyediakan, mengelola, dan mengoperasikan Layanan Pinjam Meminjam Uang Berbasis Teknologi Informasi. ${ }^{9}$ Dalam pasal 2 Peraturan OJK menyebutkan bahwa penyeleggara Layanan Pinjam Meminjam Uang Berbasis Teknologi Informasi dinyatakan sebagai Lembaga Keuangan Lainnya yang harus berbentuk Perseroan Terbatas atau Koperasi. Pihak yang selanjutnya yaitu Penerima Pinjaman adalah orang dan/atau badan hukum yang mempunyai utang karena perjanjian Layanan Pinjam Meminjam Uang Berbasis Teknologi Informasi. $^{10}$ Penerima Pinjaman

${ }^{8}$ Pasal 1 angka 8 Peraturan Otoritas Jasa Keuangan Nomor 77/PJOK.01/2016 tentang Layanan Pinjam Meminjam Uang Berbasis Teknologi Informasi.

${ }^{9}$ Pasal 1 angka 6 Peraturan Otoritas Jasa Keuangan Nomor 77/PJOK.01/2016 tentang Layanan Pinjam Meminjam Uang Berbasis Teknologi Informasi.

10 Pasal 1 angka 7 Peraturan Otoritas Jasa Keuangan Nomor 77/PJOK.01/2016 tentang Layanan Pinjam Meminjam Uang Berbasis Teknologi Informasi. 


\section{IURNAL JENDELA HUKUM}

ISSN Cetak E Online : 2355-5831/ 2355-9934

merupakan orang atau badan hukum yang membutuhkan atau kekurangan dana. Dalam prakteknya, Penyelenggara akan mempertemukan pemberi pinjaman dengan penerima pinjaman melalui sistem online.

Fintech berbasis P2P lending di Indonesia mulai berkembang, hal tersebut dapat dilihat dari banyaknya perusahaanperusahaan sebagai penyelenggara yang telah terdaftar di Otoritas Jasa Keuangan (OJK). Perkembangan Fintech berbasis P2P lending itu dikarenakan sistem pinjam meminjam uang yang ditawarkan lebih cepat dan mudah daripada meminjam uang di bank konvensional yang memerlukan waktu cukup lama karena harus memenuhi persyaratan yang telah ditentukan oleh perbakan. Selain itu Fintech berbasis $P 2 P$ lending dilakukan melalui jaringan internet sehingga berdampak luas dan meningkatkan partisipasi publik dalam jasa keuangan. Kemudahan yang ditawarkan oleh Fintech berbasis $P 2 P$ lending juga terletak pada mekanismenya, jika Penyelenggara telah memiliki investor dalam hal ini pemberi pinjaman, maka penyelenggara siap untuk memberikan pinjaman dan prosesnya terdapat di Website penyelenggara sehingga penerima pinjaman hanya mengikuti prosedur yang telah ditetapkan oleh penyelenggara untuk mendapatkan pinjaman uang secara online.

Perusahaan-Perusahan yang telah terdaftar dan mendapatkan izin OJK pada
April 2018 sebanyak 51 Perusahaan dengan klasifikasi 50 penyelenggara konvensional dan 1 penyelenggara syari'ah. Kemudian bertambah hingga Juni 2018 sebanyak 63 Perusahaan dengan klasifikasi 61 penyelenggara konvensional dan 2 penyelenggara syari'ah. ${ }^{11}$ Fenomena berkembangnya Perusahaan Fintech ini tidak dapat dibendung, tetapi seyogyanya harus diawasi dan diatur dengan baik agar dapat berguna bagi masyarakat maupun pelaku usaha di Indonesia.

Beberapa perusahaan penyelenggara yang telah beroperasi di Indonesia diantaranya PT. Digital Alpha Indonesia (Uangteman), PT. Mediator Komunitas Indonesia (Crowdo), PT. Cicil Solusi Mitra Teknologi (Cicil), PT. Akseleran Keuangan Inklusif Indonesia (Akseleran), PT. Fintegra Homido Indonesia (Fintag), dan masih banyak Perusahaan penyelenggara lainnya dengan berbagai kemudahan yang ditawarkan melalui konten website untuk menarik minat Investor dan Peneriman Pinjaman.

Berdasarkan beberapa syarat dan ketentuan serta cara kerja yang dijelaskan oleh masing-masing perusahaan atau penyeleggara diatas, maka dapat diketahui bahwa Perusahaan atau Penyelenggara hanya sebagai penyedia

\footnotetext{
${ }^{11}$ Website OJK
} 


\section{JURNAL JENDELA HUKUM}

ISSN Cetak E Online : 2355-5831/ 2355-9934

wadah bertemunya Pemberi Pinjaman dengan Penerima Pinjaman. Bahkan di Website Penyelenggara (Crowdo) menyatakan secara tegas bahwa :

1. Layanan Pinjam Meminjam Berbasis Teknologi Informasi merupakan kesepakatan perdata antara Pemberi Pinjaman dengan Penerima Pinjaman, sehingga segala risiko yang timbul dari kesepakatan tersebut ditanggung sepenuhnya oleh masing-masing pihak.

2. Risiko kredit atau gagal bayar ditanggung sepenuhnya oleh Pemberi Pinjaman. Tidak ada lembaga atau otoritas negara yang bertanggung jawab atas risiko gagal bayar ini.

3. Penyelenggara dengan persetujuan dari masing-masing Pengguna (Pemberi Pinjaman dan/atau Penerima Pinjaman) mengakses, memperoleh, menyimpan, mengelola dan/atau menggunakan data pribadi Pengguna ('Pemanfaatan Data') pada atau di dalam benda, perangkat elektronik (termasuk smartphone atau telepon seluler), perangkat keras (hardware) maupun lunak (software), dokumen elektronik, aplikasi atau sistem elektronik milik Pengguna atau yang dikuasai Pengguna, dengan memberitahukan tujuan, batasan dan mekanisme Pemanfaatan Data tersebut kepada Pengguna yang bersangkutan sebelum memperoleh persetujuan yang dimaksud.
4. Pemberi Pinjaman yang belum memiliki pengetahuan dan pengalaman pinjam meminjam, disarankan untuk tidak menggunakan layanan ini.

5. Penerima Pinjaman harus mempertimbangkan tingkat bunga pinjaman dan biaya lainnya sesuai dengan kemampuan dalam melunasi pinjaman.

6. Setiap kecurangan tercatat secara digital di dunia maya dan dapat diketahui masyarakat luas di media sosial.

7. Pengguna harus membaca dan memahami informasi ini sebelum membuat keputusan menjadi Pemberi Pinjaman atau Penerima Pinjaman.

8. Pemerintah yaitu dalam hal ini Otoritas Jasa Keuangan, tidak bertanggung jawab atas setiap pelanggaran atau ketidakpatuhan oleh Pengguna, baik Pemberi Pinjaman maupun Penerima Pinjaman (baik karena kesengajaan atau kelalaian Pengguna) terhadap ketentuan peraturan perundang-undangan maupun kesepakatan atau perikatan antara Penyelenggara dengan Pemberi Pinjaman dan/atau Penerima Pinjaman. $^{12}$

Peringatan tersebut juga serupa

12 PT. Mediator Komunitas Indonesia, welcome to Crowdo, https://crowdo.co.id/account/login, di akses pada tanggal 27 September 2018. 


\section{JURNAL JENDELA HUKUM}

ISSN Cetak E Online : 2355-5831/ 2355-9934

dengan peringatan yang tertera di beberapa website seperti Uangteman dan Investree, maka jelas bahwa hubungan hukum yang terbentuk hanya antara Pemberi Pinjaman dengan Penerima Pinjaman, sedangkan pihak perusahaan sebagai penyelenggara yang bertugas untuk merekomendasikan, menyeleksi dan melakukan analisis bukan termasuk para pihak dalam perjanjian tersebut. Jika di gambarkan hubungan hukum para pihak sebagai berikut :

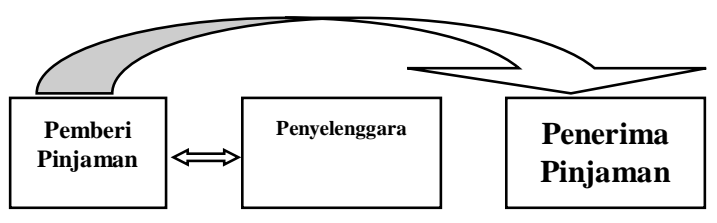

Ketiadaan hubungan hukum penyelenggara akan menyebabkan Penyeleggara tidak bertanggunggung jawab jika terjadi gagal bayar penerima pinjaman kepada pemberi pinjaman, hal ini akan menimbulkan konsekuensi hukum. Pemberi pinjaman tidak dapat melakukan tuntutan terhadap Penyelenggara jika terjadi wanprestasi sehingga kerugian sepenuhnya ditanggung oleh pemberi pinjaman. Oleh karena itu Pemberi Pinjaman harus mendapatkan Perlindungan Hukum apabila dana yang di investasikan oleh pemberi pinjaman hilang atau disalahgunakan oleh penyelenggara atau dana hilang akibat gagal bayar dari penerima pinjaman, perlindungan dimaksud untuk memberikan kepastian hukum bagi para pihak khususnya pemberi pinjaman agar keberlangsungan dunia bisnis dan investasi di Indonesia tetap terjamin.

Berdasarkan pemaparan di atas, maka penulis bermaksud untuk melakukan penelitian hukum dengan Judul "Tinjauan yuridis penyelenggaraan financial technology berbasis peer to peer lending”.

\section{B. PEMBAHASAN}

Para pihak dalam penyelenggaraan Financial Technology berbasis Peer to peer Lending di Indonesia terdiri dari pemberi pinjaman, penyelenggara dan penerima pinjaman. Sejak adanya penyelenggaraan peminjaman uang berbasis teknologi ini yang menjadi isu utama adalah bentuk perlindungan hukum khusunya bagi pemberi pinjaman, pemberi pinjaman sebagai Investor harus dilindungi agar dananya tidak hilang atau disalahgunakan oleh pihak penyelenggara dan agar dananya tidak hilang akibat gagal bayar oleh pihak penerima pinjaman (debitor).

Regulasi yang mengatur penyelenggaraan Financial Technology berbasis Peer to peer Lending di Indonesia didasarkan pada UndangUndang No. 08 Tahun 1999 tentang Perlindungan Konsumen, Undang-undang No. 40 Tahun 2007 tentang Perseroan Terbatas, Undang-undang No. 11 Tahun 2008 tentang Informasi dan Transaksi Elektronik, Undang-undang No. 21 


\section{JURNAL JENDELA HUKUM}

ISSN Cetak E Online : 2355-5831/ 2355-9934

Tahun 2011 tentang Otoritas Jasa Keuangan dan Peraturan OJK No. 77/PJOK.01/2016 Tentang Layanan Pinjam Menimjam Uang Berbasis Teknologi Infornasi.

Bentuk perlindungan hukum bagi pemberi pinjaman dapat dilakukan secara preventif maupun secara represif. Perlindungan hukum secara preventif digunakan untuk mencegah agar tidak terjadi sengketa bisnis pinjam meminjam uang berbasis teknologi. Perlindungan secara preventif tugasnya terletak pada penyelenggara Fintech dimana, penyelenggara harus memenuhi persyaratan mengajukan izin menjadi penyelenggara kepada OJK sebagaimana disebutkan dalam Pasal 3 Peraturan OJK yang mengatur penyelenggara yaitu yang berbentuk badan hukum perseroan terbatas dapat didirikan dan dimiliki oleh warga negara Indonesia dan atau badan hukum Indonesia dan/atau warga negara asingdan/ataubadan hukum asing. Kepemilikan saham Penyelenggara oleh warga negara asing dan/atau badan hukum asing sebagaimana dimaksud pada baik secara langsung maupun tidak langsung paling banyak $85 \%$ (delapan puluh lima persen). ${ }^{13}$

Penyelenggara berbentuk badan hukum perseroan terbatas wajib memiliki modal disetor paling sedikit

13 Lihat Pasal 3 Peraturan OJK No. 77/PJOK.01/2016 tentang Layanan Pinjam Meminjam Uang Berbasis Teknologi Informasi.
Rp1.000.000.000,00 (satu miliar rupiah) pada saat pendaftaran. Begitupun dengan Penyelenggara berbentuk badan hukum koperasi wajib memiliki modal sendiri paling sedikit Rp1.000.000.000,00 (satu miliar rupiah) pada saat pendaftaran. pada saat mengajukan permohonan perizinan penyelenggara wajib memiliki dana sebesar Rp2.500.000.000,00 (dua miliar lima ratus juta rupiah). ${ }^{14}$

Penyelenggara sebagai fasilitator bertindak menyediakan, mengelola dan mengoperasikan layanan pinjam meminjam berbasis teknologi informasi dari pihak pemberi pinjaman kepada penerima pinjaman. Dimana sumber dana berasal dari pemberi pinjaman sehingga penyelenggara dilarang untuk menjadi pemberi pinjaman maupun penerima pinjaman. Selain itu, penyelenggara wajib memenuhi batas maksimum pemberian pinjaman kepada penerima pinjaman sebesar 2.000.0000.000 (dua milyar). ${ }^{15}$

Selain itu, penyelenggara harus memperhatikan prinsip dasar dari perlindungan pengguna yaitu pemberi pinjaman maupun penerima pinjaman sebagaimana dijelaskan dalam peraturan OJK pasal 29 No. 77/PJOK.01/2016 yaitu terdiri dari transparansi, Perlakuan yang adil, Keandalan, Kerahasiaan dan keamanan data; dan Penyelesaian

\footnotetext{
14 Lihat Pasal 4, Ibid

${ }^{15}$ Lihat Pasal 6, Ibid
} 
sengketa pengguna secara sederhana, cepat, dan biaya terjangkau. ${ }^{16}$

Dalam menjalankan kegiatan usahanya, penyelenggara dilarang :

a. Melakukan kegiatan usaha selain kegiatan usaha penyelenggara yang diatur dalam peraturan ojk ini;

b. Bertindak sebagai pemberi pinjaman atau penerima pinjaman;

c. Memberikan jaminan dalam segala bentuknya atas pemenuhan kewajiban pihak lain;

d. Menerbitkan surat utang;

e. Memberikan rekomendasi kepada pengguna;

f. Mempublikasikan informasi yang fiktif dan/atau menyesatkan;

g. Melakukan penawaran layanan kepada pengguna dan/atau masyarakat melalui sarana komunikasi pribadi tanpa persetujuan pengguna; dan

h. Mengenakan biaya apapun kepada pengguna atas pengajuan pengaduan. $^{17}$

Bagi penyelenggara yang melanggar larangan sebagaimana pasal 43 No. 77/PJOK.01/2016 maka dikenakan sanksi administratif sebagai berikut :

a. Peringatan tertulis;

b. Denda, yaitu kewajiban untuk membayar sejumlah uang tertentu; c. Pembatasan kegiatan usaha; dan

d. Pencabutan izin.

Jadi, dalam peraturan OJK telah dijamin perlindungan secara preventif dengan baik, utamanya perlindungan ditujukan kepada pemberi pinjaman dengan memberikan peraturan yang ketat bagi penyelenggara mulai dari pendaftaran dan izin menjalankan usaha hingga larangan dan sanksi tegas berupa pencabutan izin usaha dalam penyelenggaraan Financial Technologi berbasis $P 2 P L$.

Perlindungan secara represif dilakukan setelah terjadi sengketa dalam bisnis Fintech berbasis P2PL. Jika terjadi sengketa maka pihak yang dirugikan dalam hal ini pemberi pinjaman wajib melakukan pengaduan kepada Penyelenggara. Jika, terjadi gagal bayar oleh penerima pinjaman, dan hal tersebut terjadi karena kelalaian dan kealasahan dari pihak penyelenggara, maka penyelenggara wajib melakukan ganti rugi sebagaimana disebutkan dalam pasal 37 PJOK No. 77/PJOK.01/2016 yang berbunyi :

"Penyelenggara wajib bertanggung jawab atas kerugian Pengguna yang timbul akibat kesalahan dan/atau kelalaian, Direksi, dan/atau pegawai Penyelenggara".

\footnotetext{
${ }^{16}$ Lihat Pasal 29, Ibid

${ }^{17}$ Lihat Pasal 43, Ibid
} 


\section{KESIMPULAN}

Para pihak dalam penyelenggaraan Fintech berbasis $\mathrm{P} 2 \mathrm{Pl}$ terdiri dari pemberi pinjaman (investor), penyelenggra dan penerima pinjaman. Hubungan hukum yang terbentuk antara pemberi pinjaman dengan penyelenggara adalah kuasa khusus, dimana pihak pemberi pinjaman memberikan kuasa kepada penyelenggara untuk menyalurkan dananya. Selain itu, hubungan hukum kedua yaitu antara pemberi pinjaman dengan penerima pinjaman hubungan hukum yang terbentuk yaitu hutang piutang dimana pemberi pinjaman bertindak sebagai kreditur dan penerima pinjaman sebagai debitur. Berdasarkan hubungan hukum tersebut, maka hanya terjadi perjanjian antara pemberi pinjaman dengan penerima pinjaman, sementara penyelenggara bukan termasuk para pihak dalam perjanjian tersebut. Dalam hal ini jika terjadi maka yang paling rentan dirugikan yaitu pemberi pinjaman jika. Oleh karena perlu diberikan perlindungan hukum yang jelas bagi pemberi pinjaman.

Perlindungan hukum bagi pemberi pinjaman ada dua (2) yaitu perlindungan hukum secara preventif dan perlindungan hukum secara represif. Perlindungan preventif terletak pada penyelenggara dengan memberikan peraturan yang ketat bagi penyelenggara mulai dari pendaftaran dan izin menjalankan usaha hingga larangan dan sanksi tegas berupa pencabutan izin usaha dalam penyelenggaraan Financial Technologi berbasis $P 2 P L$.

Selain itu, penyelenggara wajib menerapkan prinsip dasar dari perlindungan pengguna yaitu pemberi pinjaman maupun penerima pinjaman sebagaimana dijelaskan dalam peraturan OJK pasal 29 No. 77/PJOK.01/2016 yaitu terdiri dari transparansi, Perlakuan yang adil, Keandalan, Kerahasiaan dan keamanan data; dan Penyelesaian sengketa pengguna secara sederhana, cepat, dan biaya terjangkau.

Perlindungan secara represif yaitu jika telah terjadi sengketa karena kelalaian dan kealasahan dari pihak penyelenggara, maka penyelenggara wajib melakukan ganti rugi sebagaimana disebutkan dalam pasal 37 PJOK No. 77/PJOK.01/2016.

\section{DAFTAR BACAAN}

\section{Buku}

Djoni S. Gazali, Rachmadi Usman, Hukum Perbankan, Sinar Grafika, Jakarta, 2016.

Fauziah Hadi, Penerapan Financial Technology (Fintech) sebagai Inovasi Pengembangan Keuangan Digital di Indonesia.

Nofie Iman, Financial Technology dan Lembaga Keuangan, Gathering Mitra Linkage Bank Syariah Mandiri, Yogyakarta, 2016.

Peter Machmud Marzuki, Penelitian Hukum, Kencana Prenada Media Grup, Jakarta, 2011. 


\section{Peraturan Perundang-undangan}

Undang-Undang Dasar Negara Republik Indonesia 1945;

Undang-Undang No. 10 Tahun 1998 Perubahan atas Undang-Undang No. 7 Tahun 1992 tentang Perbankan;

Undang-Undang No. 08 Tahun 1999 tentang Perlindungan Konsumen,

Undang-undang No. 40 Tahun 2007 tentang Perseroan Terbatas,

Undang-undang No. 11 Tahun 2008 tentang Informasi dan Transaksi Elektronik

Undang-Undang No. 21 tahun 2011 tentang Otoritas Jasa Keuangan;

Peraturan OJK No. 77/PJOK.01/2016 Tentang Layanan Pinjam Menimjam Uang Berbasis Teknologi Infornasi.

\section{Jurnal Ilmiah}

Ross P. Buckley, "FinTech in Developing Countries : Charting New Costumers Journeys" Jurnal : The Capco Institute Journal of Financial Transformation. 2016. 